\title{
- ORAL PRESENTATIONS -
}

\section{ASSESSMENT OF THE POTENTIAL ECOLOGICAL RISK WITH HEAVY METALS IN SURFACE SEDIMENTS FROM ACCUMULATION LAKES ON THE SECTOR INFERIOR OF THE OLT RIVER}

\author{
Mihaela lordache ${ }^{1}$, Luisa Roxana Popescu ${ }^{1,3}$, Luoana Florentina Pascu ${ }^{2}$, \\ loan lordache ${ }^{4}$ \\ 1 National Research and Development Institute for Industrial Ecology - \\ Ramnicu Valcea Subsidiary, 1 Uzinei St., Romania \\ 2 National Research and Development Institute for Industrial Ecology - \\ Bucharest, 71-73 Podu Dambovitei Street, 060650, Bucharest, Romania \\ 3 University "Politehnica" of Bucharest, Faculty of Applied Chemistry and \\ Material Science, Gh. Polizu 1-7, 011061, Bucharest, Romania \\ ${ }_{4}$ National Research and Development Institute for Cryogenics and Isotopic \\ Technologies -ICIT, 4 Uzinei Street, 240050 Ramnicu Valcea, Romania
}

Abstract. The aim of this paper is to assess the heavy metal pollution and potential ecological risk in surface sediments from accumulation lakes on the sector inferior of the Olt River: Govora, Babeni-Marcea, Zavideni, Dragasani and Strejesti. Heavy metals are among the most persistent of pollutants in the ecosystem such as water, sediments and biota because of their resistance to decomposition in natural condition. Accumulation of heavy metals in the environment results primarily from human activity. In addition, an important role in the "enrichment" heavy metal reservoirs they have natural processes, such as the disintegration of rocks and volcanic activities. Sediment is the ultimate destination for heavy metals discharged into the environment. The main aspects of the present work are to: determine to content and spatial distribution of heavy metals $(\mathrm{Cd}, \mathrm{Cu}, \mathrm{Ni}, \mathrm{Zn}, \mathrm{Pb}, \mathrm{Cr}, \mathrm{Hg})$ in surface sediments from accumulation lakes on the sector inferior of the Olt River; calculating the pollution load index (PLI), the Nemerow pollution index (PI) and potential ecological risk (RI) in order to evaluate the potential ecological risk.

Keywords: heavy metals, surface sediment, accumulation lakes, potential ecological risk

\section{AIMS AND BACKGROUND}

Heavy metals are among the most persistent of pollutants in the ecosystem such as water, sediments and biota because of their resistance to decomposition in natural condition. Metal have low solubility in water, get adsorbed and accumulated on bottom sediments ${ }^{1}$.

The increase the heavy metal content in the reservoirs is shown notably by increasing their concentration in bottom sediments. Accumulation of heavy metals in the environment results primarily from human activity. In addition, an 
important role in the "enrichment" heavy metal reservoirs they have natural processes, such as the disintegration of rocks and volcanic activities. Sediment is the ultimate destination for heavy metals discharged into the environment. The accumulation of heavy metals in sediment through mechanisms physical and chemical complexes of the adsorption, depending on the nature of the matrix of the sediment and the adsorption properties of the compounds ${ }^{2,3}$.

The lake sediments are basic components of our environments as they provide nutrients for living organism. Lake bottom sediments are sensitive indicators for monitoring contaminants as they can act as a sink and a carrier for pollutants in the aquatic environment. Thus, the lake sediment analysis plays an important role in evaluating pollution status in aquatic environment ${ }^{4}$.

Environmental pollution by heavy metals has become a global phenomenon with a special significance. The introduction of heavy metals in aquatic systems causes the deterioration of a number of biochemical processes that lead to dam-age of the flora and fauna of the aquatic system ${ }^{5}$.

Sediment has widely been studied for anthropogenic impacts on the aquatic environment ${ }^{6}$. Various studies have reported sediment quality assessments, distribution and contamination of heavy metals and quantification of pollution load in sediments of different rivers such has the Haihe River, China $^{7}$, the Jialu River, China ${ }^{8}$, the Lancang River, China ${ }^{9}$, the Turag River, Banglades ${ }^{10}$, the Hindon River, India ${ }^{11}$, the Chao Phraya River, Thailanda ${ }^{12}$, the Kurang River, Pakistan ${ }^{6}$, the Euphrates River, Turcia ${ }^{13}$, the Euphrates River, Iraq $^{14}$, the Olt River, Romania ${ }^{15,16}$, the Danube River, Romania ${ }^{17,}{ }^{18}$, water reservoirs Bakomi, Rozgrund and Vindsachta, Slovakia ${ }^{19}$, the Shkodra lake, Albania ${ }^{5}$.

The main aspects of the present work are to: determine to content and spatial distribution of heavy metals ( $\mathrm{Cd}, \mathrm{Cu}, \mathrm{Ni}, \mathrm{Zn}, \mathrm{Pb}, \mathrm{Cr}, \mathrm{Hg}$ ) in surface sediments from accumulation lakes on the sector inferior of the Olt River; calculating the pollution load index (PLI), the Nemerow pollution index (PI) and potential ecological risk $(\mathrm{RI})$ in order to evaluate the potential ecological risk.

\section{EXPERIMENTAL}

To assess the heavy metal pollution and potential ecological risk in surface sediments from accumulation lakes on the sector inferior of the Olt River, samples were collected from the upper layer of sediment, in five accumulation lakes: Govora, Babeni-Marcea, Zavideni, Dragasani and Strejesti. Sediment samples were collected in February 2015 from 9 sites distributed along the study area (Fig.1).

\section{Determination of metals}

Sediments samples into plastic bags were collected, and preserved by adding a small amount of concentrated nitric acid. Samples were air-dried. Mix the sample thoroughly to achieve homogeneity and sieve $(<0.2 \mathrm{~mm})$, if appropriate and necessary. For each digestion procedure, weigh to the nearest $0.01 \mathrm{~g}$ and transfer $2.0 \mathrm{~g}$ sample (dry weight) to a digestion vessel. The digestion test samples by AAS, was made by adding a mixture of $5 \mathrm{ml} \mathrm{HNO}(65 \%)$ and $15 \mathrm{ml}$ of $\mathrm{HCl}(38 \%)$. The sample is kept for 16 hours at room temperature to permit slow oxidation of the organic matter in the sediment. Reaction mixture 
temperature is increased slightly until it reaches boiling point and is maintained for 2 hours, then let cool. The mixture is passed through filter paper and collected in a $100 \mathrm{~mL}$ flask. The filter paper was washed with $\mathrm{HNO}_{3} 0.5 \mathrm{M}$ acid aqueous solutions. $100 \mathrm{~mL}$ flask is filled up to the mark with distilled water. Determination of the heavy metals in sediments was performed according to ISO 11466/1999 and ISO 11047/1999.

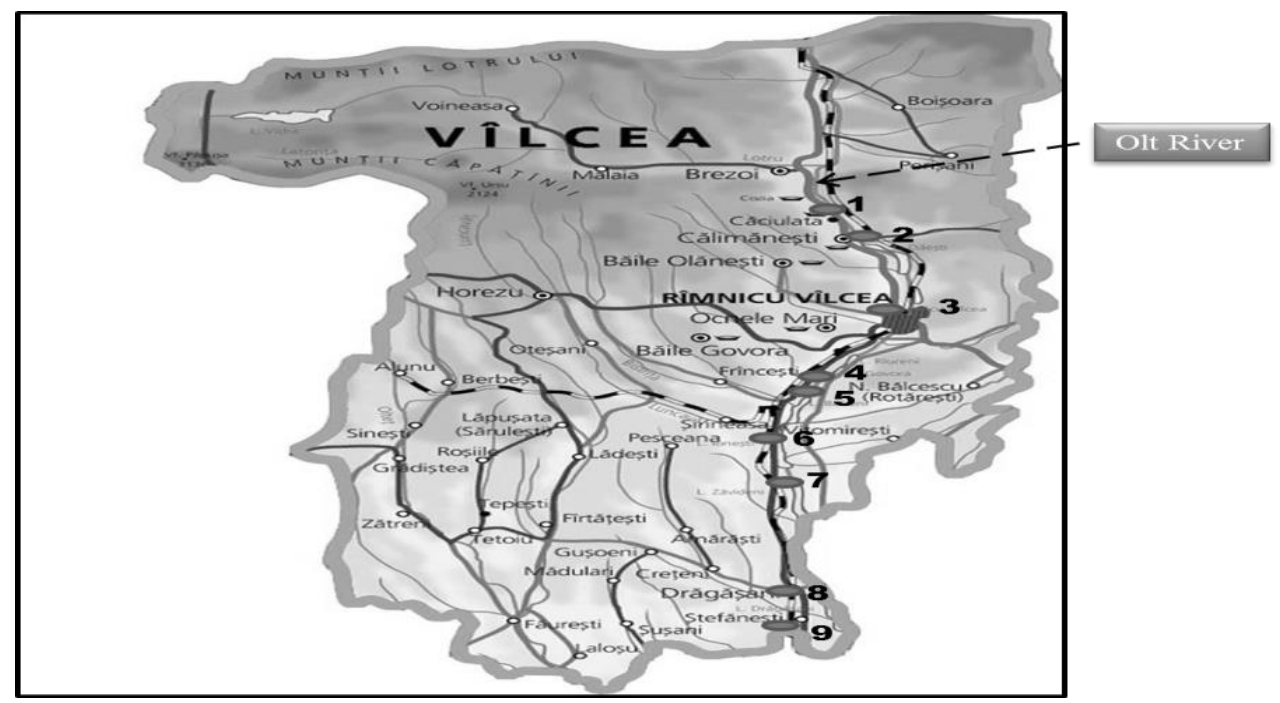

Figure 1. Localization points

\section{Quantification of sediment pollution}

For assessment of the pollution degree with heavy metals in sediment four parameters have been used: Contamination factor (CF), Pollution load index $(\mathrm{PLI})$, Nemerow pollution index $(\mathrm{PI})$ and the Ecological risk index (RI).

Contamination factor (CF)

The contamination factor (CF) was used to determine the contamination status of sediments and it is calculated as the ratio obtained by dividing the concentration of each heavy metal in the sediment $\left(C_{\text {metal }}\right)$ by the concentration in background (Bn) (Eq.1).

Depending on its value, the sediment pollution degree is classified as shown in Table 1.

$$
C F=\frac{C_{\text {metal }}}{B n}
$$

Table 1. Contamination levels of sediments according to values of contamination factor

\begin{tabular}{|c|c|}
\hline $\begin{array}{c}\text { Contamination factor } \\
(\mathbf{C F})\end{array}$ & Contamination level \\
\hline $\mathbf{C F}<\mathbf{1}$ & Low \\
\hline $\mathbf{1} \leq \mathbf{C F}<\mathbf{3}$ & Moderate \\
\hline $\mathbf{3} \leq \mathbf{C F}<\mathbf{6}$ & Considerable \\
\hline $\mathbf{C F}>\mathbf{6}$ & Very high \\
\hline
\end{tabular}


Pollution load index (PLI)

Pollution load index (PLI) is calculated as the following (Eq. 2):

$$
P L I=(C F 1 \times C F 2 \times C F 3 \times \ldots . . C F n)^{1 / n}
$$

where, " $n$ " is the number of metals, $C F$ is contamination factor.

The PLI provides simple bat comparative means for assessing a site quality, where a value of $\mathrm{PLI}<1$ denotes perfection; $\mathrm{PLI}=1$ presents that only baseline levels of pollutants are presented and PLI $>1$ would indicate deterioration of site quality.

Nemerow pollution index (PI)

The Nemerow pollution index ${ }^{20}$, (PI; Eq. 3) was used to determine whether or not sampling sites were polluted in comparison with the criteria given in Table 2.

$$
P I=\sqrt{\frac{(\overline{C F})^{2}+(C F \max )^{2}}{2}}
$$

Table 2. Nemerow pollution index sediment quality indicators

\begin{tabular}{|c|c|}
\hline $\begin{array}{c}\text { PI value } \\
\text { Qualification of } \\
\text { sediment }\end{array}$ & $\begin{array}{c}\text { PI value Qualification of } \\
\text { sediment }\end{array}$ \\
\hline PI $<\mathbf{0 . 7}$ & Non-polluted sediment \\
\hline $\mathbf{0 . 7}<$ PI $<\mathbf{1}$ & Nearly polluted sediment \\
\hline $\mathbf{1}<$ PI $<\mathbf{2}$ & Lightly polluted sediment \\
\hline $\mathbf{2}<$ PI $<\mathbf{3}$ & Moderately polluted sediment \\
\hline $\mathbf{3}<$ PI & Seriously polluted sediment \\
\hline
\end{tabular}

Potential ecological risk (RI)

In 1980, Lars Hakanson reported an ecological risk index for aquatic pollution control; therefore, Hakanson' method has been often used in ecological risk assessment as a diagnostic tool to penetrate one of many possible avenues towards a potential ecological risk index, i.e., to sort out which drainage area, reservoir, and substances should be given special attention ${ }^{7,10,21,22}$ (Tables 4).

The index is calculated as the following equations (4), (5), (6), (7), (8):

$$
\begin{aligned}
& C F=\frac{C_{\text {metal }}}{B n} \\
& C H=\sum_{i=1}^{n} C F \\
& m C H=\frac{\sum_{i=1}^{n} C F}{n} \\
& E f=T f \times C F
\end{aligned}
$$




$$
R I=\sum_{i=1}^{n} E f
$$

where $C F$ is the contamination factor; $C_{H}$ is the polluted coefficient of many metals; $m C_{H}$ is the modified degree of contamination factors; $E_{f}$ is the potential ecological risk factor of single metal; $T_{f}$ is the biological toxicity factor of individual metals, which are defined $\mathrm{as}^{12}: \mathrm{Cd}=30, \mathrm{Cr}=2, \mathrm{Cu}=\mathrm{Ni}=\mathrm{Pb}=5, \mathrm{Zn}=1$, $\mathrm{Hg}=40$.

Table 3. Grade standard of $\mathrm{Ef}$ and $\mathrm{RI}^{4}$

\begin{tabular}{|c|c|c|}
\hline $\begin{array}{c}\text { Pollution } \\
\text { coefficient } \\
\text { (Ef) }\end{array}$ & $\begin{array}{c}\text { Pollution } \\
\text { index } \\
\text { (RI) }\end{array}$ & Pollution level \\
\hline$<40$ & $<150$ & Light ecological risk \\
\hline $\mathbf{4 0 - 7 9}$ & $150-299$ & Middle ecological risk \\
\hline $\mathbf{8 0 - 1 5 9}$ & $300-600$ & Strong ecological risk \\
\hline $\mathbf{1 6 0 - 3 2 0}$ & $>600$ & Very strong ecological risk \\
\hline$>\mathbf{3 2 0}$ & - & Extremely strong ecological risk \\
\hline
\end{tabular}

\section{RESULTS AND DISCUSSION}

\section{Heavy metal concentration in sediments}

To assess the contamination degree of sediments in the studied area, samples were collected from the upper layer of sediment, in nine points. Table 4 shows the concentrations of heavy metals in sediments from accumulation lakes on the sector inferior of the Olt River. The analyzes were compared with the national legislation regulations ${ }^{23}$. The concentration range of metals in sediments is: 16.8 and $107.3 \mathrm{mg} / \mathrm{kg}$ d.w. for $\mathbf{N i}, 9.19$ and $473 \mathrm{mg} / \mathrm{kg}$ d.w. for $\mathbf{C u}, 8.86$ and $42.6 \mathrm{mg} / \mathrm{kg}$ d.w. for $\mathbf{C r}, 6.2$ and $74.9 \mathrm{mg} / \mathrm{kg}$ d.w. for $\mathbf{Z n}, 0.74$ and $3.36 \mathrm{mg} / \mathrm{kg}$ d.w. for $\boldsymbol{H g}$. The metals $\boldsymbol{P b}$ and $\boldsymbol{C d}$ had values below the detection limit of the method. Higher concentrations of $\mathbf{N i}$ were found in sediments of the points S2 and S4 (upstream of the industrial platform), $\mathbf{C u}$ was found of the points S2, S3 and S4 (upstream of the industrial platform), $\mathbf{Z n}$ was found in sediments of the points S2, S4 (upstream of industrial platform) and S5 (dowstream of the industrial platform - accumulation lake Babeni) while higher concentrations of $\mathrm{Cr}$ was found in sediments of the point S2 (upstream of the industrial platform). Higher concentrations of $\boldsymbol{H g}$ were found in sediments of the points S2, S3, S4 (upstream of the industrial platform) and S5 (downstream of the industrial platform - accumulation lake Babeni).

From the results are observed accumulation of metals $(\mathrm{Ni}, \mathrm{Cu}, \mathrm{Zn}, \mathrm{Cr}$ and $\mathrm{Hg}$ ) greater in the upstream of the industrial platform Ramnicu Valcea to the downstream sections, which can be deduced that such pollution sources could be Ramnicu Valcea city and industrial activities placed upstream from the Olt River. Another explanation for the lower concentration of heavy metals in points situated downstream of the industrial platform is the presence the Govora dam, which retains significant amounts of sediment ${ }^{15}$. 
Table 4. The content of metals in sediments of the Olt River (mg/kg d.w.)

\begin{tabular}{|c|c|c|c|c|c|c|c|c|c|}
\hline $\begin{array}{c}\text { Sample } \\
\text { designation }\end{array}$ & The period & $\mathbf{p H}$ & $\mathbf{C r}$ & $\mathbf{N i}$ & $\mathbf{C u}$ & $\mathbf{Z n}$ & $\mathbf{C d}$ & $\mathbf{H g}$ & $\mathbf{P b}$ \\
\hline S1 & February 2015 & 7.85 & $<1.0$ & $<1.0^{*}$ & 9.19 & 12.08 & $<0.1^{*}$ & $\mathbf{0 . 9 9}$ & $<1.0^{*}$ \\
\hline S2 & February 2015 & 7.71 & 42.6 & $\mathbf{5 7 . 9}$ & $\mathbf{4 4 . 2}$ & 74.9 & $<0.1^{*}$ & $\mathbf{1 . 7 8}$ & $<1.0^{*}$ \\
\hline S3 & February 2015 & 8.28 & 7.85 & $<1.0^{*}$ & $\mathbf{4 7 3 . 0}$ & 13.3 & $<0.1^{*}$ & $\mathbf{3 . 3 6}$ & $<1.0^{*}$ \\
\hline S4 & February 2015 & 7.98 & $<1.0^{*}$ & $\mathbf{1 0 7 . 3}$ & $\mathbf{5 2 . 7}$ & 65.9 & $<0.1^{*}$ & $\mathbf{0 . 9 8}$ & $<1.0^{*}$ \\
\hline S5 & February 2015 & 8.05 & 9.28 & 29.4 & 21.9 & 46.4 & $<0.1^{*}$ & $\mathbf{1 . 0 4}$ & $<1.0^{*}$ \\
\hline S6 & February 2015 & 8.16 & $<1.0^{*}$ & 16.8 & $<1.0^{*}$ & $<1.0^{*}$ & $<0.1^{*}$ & $\mathbf{0 . 7 4}$ & $<1.0^{*}$ \\
\hline S7 & Februarie 2015 & 8.11 & 8.96 & $<1.0^{*}$ & 11.54 & 21.0 & $<0.1^{*}$ & $\mathbf{0 . 8 5}$ & $<1.0^{*}$ \\
\hline S8 & February 2015 & 8.09 & 8.86 & $<1.0^{*}$ & 11.40 & 6.20 & $<0.1^{*}$ & $\mathbf{0 . 8}$ & $<1.0^{*}$ \\
\hline S9 & February 2015 & 8.15 & $<1.0^{*}$ & $<1.0^{*}$ & 11.64 & 27.2 & $<0.1^{*}$ & $\mathbf{0 . 8 4}$ & $<1.0^{*}$ \\
\hline $\begin{array}{c}\text { Order } \\
\text { No.161/2006 }\end{array}$ & $\begin{array}{c}\text { Quality } \\
\text { standard }\end{array}$ & - & $\mathbf{1 0 0}$ & $\mathbf{3 5}$ & $\mathbf{4 0}$ & $\mathbf{1 5 0}$ & $\mathbf{0 . 8}$ & $\mathbf{0 . 3}$ & $\mathbf{8 5}$ \\
\hline
\end{tabular}

* The limit of detection of the method

\section{Assessment of sediment contamination}

For assess the heavy metal pollution of sediments were used parameters: the contamination factor (CF), the ecological risk index (RI), the pollution load index (PLI) and Nemerow pollution index (PI).

\section{Contamination factor (CF)}

From the determination of contamination factor (CF) in sediments from the Olt River was found a moderate contamination with $\mathbf{N i}$ in point S3 (upstream of the chemical platform - lake accumulation Govora) and downstream of the chemical platform in points: S7 (Zavideni accumulation lake), S8 (Dragasani accumulation lake) and S9 (Strejesti accumulation lake), with $\mathbf{Z n}$ in point S3 (upstream of the chemical platform - Govora accumulation lake) and downstream of the chemical platform in point $S 7$ (Zavideni accumulation lake). There was found a moderate contamination with $\mathbf{H g}$ in point S2 (upstream of Ramnicu Valcea - approx. $10 \mathrm{~km}$ ) and in point S5 (downstream of the chemical platform - lake accumulation Babeni) with $\boldsymbol{C r}$ in point $\mathrm{S} 4$ (upstream of the chemical platform - lake accumulation Govora) and downstream of the chemical platform in points: S6 (Babeni accumulation lake) and S9 (Strejesti accumulation lake). There was a considerable contamination with $\mathrm{Hg}$ upstream of the chemical platform in point S3 (Govora accumulation lake), with $\mathrm{Cu}$ in point S4 (upstream of the chemical platform - Govora accumulation lake) and with $\mathbf{Z n}$ in point S4 (upstream of the chemical platform - lake accumulation Govora) and in point S5 (downstream of the chemical platform - Babeni accumulation lake). There was found a high contamination with $\mathbf{N i}$ in point S2 (upstream of the Ramnicu Valcea), in point S4 (upstream of chemical platform Govora accumulation lake), in points S5 and S6 (downstream of the chemical platform - Babeni accumulation lake (S5 and S6), with $\mathrm{Cu}$ in point S3 (upstream of the chemical platform - Govora accumulation lake), with $\mathbf{Z n}$ in point S2 (upstream of the Ramnicu Valcea - approx. $10 \mathrm{~km}$ ) (Tables 5a and 5b). 
Table 5a. Contamination factor (CF) for heavy metals in sediments of the Olt River

\begin{tabular}{|c|c|c|c|c|c|c|c|c|}
\hline $\begin{array}{c}\text { Sample } \\
\text { designation }\end{array}$ & \multicolumn{3}{|c|}{ Cr } & \multicolumn{2}{c|}{ Ni } & \multicolumn{2}{c|}{ Cu } & \multicolumn{2}{c|}{ Zn } \\
\hline & CF & Level & CF & Level & CF & Level & CF & Level \\
\hline S1 & 1 & $1<\mathrm{CF}<3$ & 1 & $1<\mathrm{CF}<3$ & 1 & $1<\mathrm{CF}<3$ & 1 & $1<\mathrm{CF}<3$ \\
\hline S2 & 42.6 & $\mathbf{C F}>\mathbf{6}$ & 57.9 & $\mathbf{C F}>\mathbf{6}$ & 4.8 & $\mathbf{3} \mathbf{C F}<\mathbf{6}$ & 6.2 & $\mathbf{C F}>\mathbf{6}$ \\
\hline S3 & 7.85 & $\mathbf{C F}>\mathbf{6}$ & 1 & $1<\mathrm{CF}<3$ & 51.47 & $\mathbf{C F}>\mathbf{6}$ & 1.1 & $1<\mathrm{CF}<3$ \\
\hline S4 & 1 & $1<\mathrm{CF}<3$ & 107.3 & $\mathbf{C F}>\mathbf{6}$ & 5.73 & $\mathbf{3}<\mathbf{C F}<6$ & 5.45 & $\mathbf{3}<\mathbf{C F}<\mathbf{6}$ \\
\hline S5 & 9.28 & $\mathbf{C F}>\mathbf{6}$ & 29.4 & $\mathbf{C F}>\mathbf{6}$ & 2.38 & $1<\mathrm{CF}<3$ & 3.84 & $\mathbf{3}<\mathbf{C F}<\mathbf{6}$ \\
\hline S6 & 1 & $1<\mathrm{CF}<3$ & 16.8 & $\mathbf{C F}>\mathbf{6}$ & 0.11 & $<1$ & 0.08 & $<1$ \\
\hline S7 & 8.96 & $\mathbf{C F}>\mathbf{6}$ & 1 & $1<\mathrm{CF}<3$ & 1.25 & $1<\mathrm{CF}<3$ & 1.74 & $1<\mathrm{CF}<3$ \\
\hline S8 & 8.86 & $\mathbf{C F}>\mathbf{6}$ & 1 & $1<\mathrm{CF}<3$ & 1.24 & $1<\mathrm{CF}<3$ & 0.51 & $<1$ \\
\hline S9 & 1 & $1<\mathrm{CF}<3$ & 1 & $1<\mathrm{CF}<3$ & 1.27 & $1<\mathrm{CF}<3$ & 2.25 & $1<\mathrm{CF}<3$ \\
\hline
\end{tabular}

Table $5 \mathrm{~b}$. Contamination factor (CF) for heavy metals in sediments of the Olt River

\begin{tabular}{|c|c|c|c|c|c|c|}
\hline $\begin{array}{c}\text { Sample } \\
\text { designation }\end{array}$ & \multicolumn{2}{|c|}{ Cd } & \multicolumn{2}{|c|}{ Hg } & \multicolumn{2}{c|}{ Pb } \\
\hline & CF & Level & CF & Level & CF & Level \\
\hline S1 & 1 & $1<\mathrm{CF}<3$ & 1 & $1<\mathrm{CF}<3$ & 1 & $1<\mathrm{CF}<3$ \\
\hline S2 & 1 & $1<\mathrm{CF}<3$ & 1.8 & $1<\mathrm{CF}<3$ & 1 & $1<\mathrm{CF}<3$ \\
\hline S3 & 1 & $1<\mathrm{CF}<3$ & 3.39 & $\mathbf{3}<\mathrm{CF}<6$ & 1 & $1<\mathrm{CF}<3$ \\
\hline S4 & 1 & $1<\mathrm{CF}<3$ & 0.99 & $<1$ & 1 & $1<\mathrm{CF}<3$ \\
\hline S5 & 1 & $1<\mathrm{CF}<3$ & 1.05 & $1<\mathrm{CF}<3$ & 1 & $1<\mathrm{CF}<3$ \\
\hline S6 & 1 & $1<\mathrm{CF}<3$ & 0.74 & $<1$ & 1 & $1<\mathrm{CF}<3$ \\
\hline S7 & 1 & $1<\mathrm{CF}<3$ & 0.85 & $<1$ & 1 & $1<\mathrm{CF}<3$ \\
\hline S8 & 1 & $1<\mathrm{CF}<3$ & 0.80 & $<1$ & 1 & $1<\mathrm{CF}<3$ \\
\hline S9 & 1 & $1<\mathrm{CF}<3$ & 0.85 & $<1$ & 1 & $1<\mathrm{CF}<3$ \\
\hline
\end{tabular}

\section{Pollution load index (PLI)}

Regarding of pollution load index (PLI), values are above 1 (PLI>1) in most of the points, from where is apparent "that there is a deterioration in the quality of sediments", hence there was a heavy metal pollution, except the point S6 (downstream of the chemical platform - Babeni accumulation lake), value are less than $1(\mathrm{PLI}<1)$, indicating no pollution (Table 6).

Table 6. Pollution load index (PLI) and Nemerow index (PI) for heavy metals from sediments of the Olt River

\begin{tabular}{|c|c|c|c|c|}
\hline $\begin{array}{c}\text { Sample } \\
\text { designation }\end{array}$ & PLI & Pollution level & PI & Pollution level \\
\hline S1 & 0 & Unpolluted & 0 & Unpolluted \\
\hline S2 & $\mathbf{5 . 2}$ & Polluted & $\mathbf{4 2 . 5 5}$ & Seriously polluted \\
\hline S3 & $\mathbf{2 . 7 8}$ & Polluted & $\mathbf{3 7 . 0 1}$ & Seriously polluted \\
\hline S4 & $\mathbf{3 . 1 1}$ & Polluted & $\mathbf{7 6 . 8 7}$ & Seriously polluted \\
\hline S5 & $\mathbf{3 . 0 1}$ & Polluted & $\mathbf{2 1 . 3 4}$ & Seriously polluted \\
\hline S6 & 0.73 & Lightly polluted & $\mathbf{1 2 . 0 6}$ & Seriously polluted \\
\hline S7 & $\mathbf{1 . 4 6}$ & Polluted & 6.53 & Seriously polluted \\
\hline S8 & $\mathbf{1 . 2 4}$ & Polluted & 6.43 & Seriously polluted \\
\hline S9 & $\mathbf{1 . 1 3}$ & Polluted & 1.8 & Lightly polluted \\
\hline
\end{tabular}




\section{Nemerow pollution index $(\mathrm{PI})$}

From the calculation of Nemerow Index (PI), in sediments from Olt River, was found a level of pollution "heavily polluted" in the majority points, except the point S9 (Strejesti accumulation lake) where was found a level of pollution "lightly contaminated" (Table 6).

Table 7. Ecological risk index for heavy metals from sediments of the Olt River

\begin{tabular}{|c|c|c|c|c|c|c|c|c|c|}
\hline \multirow{2}{*}{$\begin{array}{c}\text { Sample } \\
\text { designation }\end{array}$} & $\mathrm{Cr}$ & $\mathbf{N i}$ & $\mathbf{C u}$ & $\mathbf{Z n}$ & Cd & $\mathrm{Hg}$ & $\mathbf{P b}$ & \multirow[t]{2}{*}{ RI } & \multirow{2}{*}{$\begin{array}{c}\text { Grade Hakanson } \\
\text { Pollution level } \\
\end{array}$} \\
\hline & $\mathbf{E}_{\mathbf{f}}$ & $\mathbf{E}_{\mathbf{f}}$ & $\mathbf{E}_{\mathrm{f}}$ & $\mathbf{E}_{f}$ & $\mathbf{E}_{\mathbf{f}}$ & $\mathbf{E}_{\mathbf{f}}$ & $\mathbf{E}_{\mathrm{f}}$ & & \\
\hline S1 & 2 & 6 & 5 & 1 & 30 & 40 & 5 & 89 & Light ecological risk \\
\hline S2 & 85.2 & 347.4 & 24.0 & 6.2 & 30 & 71.91 & 5 & 569.7 & Strong ecological risk \\
\hline S3 & 15.7 & 6.0 & 257.3 & 1.1 & 30 & 135.75 & 5 & 450.9 & Strong ecological risk \\
\hline S4 & 2 & 643.8 & 28.67 & 5.45 & 30 & 39.6 & 5 & 754.5 & $\begin{array}{l}\text { Very strong } \\
\text { ecological risk }\end{array}$ \\
\hline S5 & 18.6 & 176.4 & 11.9 & 3.84 & 30 & 42.02 & 5 & 287.7 & Middle ecological risk \\
\hline S6 & 2 & 100.8 & 0.5 & 0.08 & 30 & 29.9 & 5 & 168.3 & Middle ecological risk \\
\hline S7 & 17.9 & 6 & 6.2 & 1.74 & 30 & 34.34 & 5 & 101.2 & Light ecological risk \\
\hline S8 & 17.7 & 6 & 6.2 & 0.51 & 30 & 32.32 & 5 & 97.7 & Light ecological risk \\
\hline S9 & 2 & 6 & 6.3 & 2.25 & 30 & 33.93 & 5 & 85.5 & Light ecological risk \\
\hline
\end{tabular}

\section{Potential ecological risk (RI)}

In sediments from Olt River it was found a low ecological risk of heavy metal downstream of the chemical platform Ramnicu Valcea: Zavideni accumulation lake (S7), Dragasani accumulation lake (S8) and Strejesti accumulation lake (S9). In sediments from Babeni Accumulation Lake (S5 and S6) situated downstream of the chemical platform Ramnicu Valcea was found a moderate ecological risk with heavy metal. The points located upstream and downstream from the city Ramnicu Valcea (S2 and S3) was found a strong ecological risk, given risk factor potential ecological risk (Ef) of $\mathrm{Ni}$ and $\mathrm{Hg}$ to a point upstream of Ramnicu Valcea (S2) from which it is apparent that there is a greater degree of pollution with metals $\mathrm{Ni}$ and $\mathrm{Hg}$ while to point downstream of Ramnicu Valcea (S3) the risk is given by $\mathrm{Cu}$ and $\mathrm{Hg}$, which proves that there a degree of pollution higher by metals $\mathrm{Cu}$ and $\mathrm{Hg}$. In sediments from Govora accumulation lake (S4) situated upstream of the platform Ramnicu Valcea was found a very strong ecological risk of heavy metal, given the risk of potential ecological risk factor (Ef) of $\mathrm{Ni}$ and $\mathrm{Cu}$ from which it is apparent that there a degree of pollution higher by $\mathrm{Ni}$ and $\mathrm{Cu}$ metals (Table 7 ).

\section{CONCLUSIONS}

In sediments from accumulation lakes on the sector inferior of the Olt River, the pollution load index (PLI) indicated a heavy metal pollution in most points, except the point S6 (downstream of the chemical platform - Babeni accumulation lake), value are less than 1 ( $P L \mid<1)$, indicating no pollution. The Nemerow index (PI) indicated a level of pollution "heavily polluted" in the majority points, except the point S9 (Strejesti accumulation lake) where was found a level of pollution "lightly contaminated". In sediments from Olt River it was found a low ecological risk of heavy metal, downstream of the chemical platform Ramnicu Valcea: Zavideni accumulation lake (S7), Dragasani 
accumulation lake (S8) and Strejesti accumulation lake (S9). In sediments from Babeni Accumulation Lake (S5 and S6) situated downstream of the chemical platform Ramnicu Valcea was found a moderate ecological risk with heavy metal. The points located upstream and downstream from the city Ramnicu Valcea (S2 and S3) was found a strong ecological risk. In sediments from Govora accumulation lake (S4) situated upstream of the platform Ramnicu Valcea was found a very strong ecological risk of heavy metal. From the results are observed accumulation of metals $(\mathrm{Ni}, \mathrm{Cu}, \mathrm{Zn}, \mathrm{Cr}$ and $\mathrm{Hg}$ ) greater in the upstream of the industrial platform Ramnicu Valcea to the downstream sections, which can be deduced that such pollution sources could be Ramnicu Valcea city and industrial activities placed upstream from the Olt River.

Acknowledgements. This study has been carried out within the frame work of the CORE Program (Environmental Research - priority in sustainable industrial development - MEDIND, PN 09-13.02.17) and the work done by L. R. POPESCU has been supported by the Sectoral Operational Programme Human Resources Development (SOP HRD), financed from the European Social Fund and the Romanian Government under the contract number POSDRU/159/1.5/S/137390/.

\section{REFERENCE}

1. F. LI, J. HUANG, G. ZENG, X. YUAN, X. LI, J. LIANG, X. WANG, X. TANG, B. BAI: Spatial risk assessment and sources identification of heavy metals in surface sediments from the Dongting Lake, Middle China, Journal of Geochemical Exploration (132), 75 - 83, (2013).

2. I. CHIRA, GHE. DAMIAN, R. CHIRA: Spatial distribution of heavy metals in the soils of Băiuţ area, Maramureş county, Romania, Carpathian Journal of Earth and Environmental Sciences, 9, (1), 269 - 278, (2014).

3. A. F. KHAN, A. ZUBAIR, M. IMRAN: Assessment of heavy metals allocation and contamination indicator in the sediments of coastal areas of Karachi, Sindh, Pakistan, Carpathian Journal of Earth and Environmental Sciences, 9, (3), 199 206, (2014).

4. G. SURESH, P. SUTHARSAN, V. RAMASAMY, R. VENKATACHALAPATHY: Assessment of spatial distribution and potential ecological risk of the heavy metals in relation to granulometric contents of Veeranam lake sediments, India, Ecotoxicology and Environmental Safety (84), 117 -124, (2012).

5. A. BEKTESHI, E. MYRTAJ, Heavy metals in the Shkodra lake ecosystem, J Environ Protect Ecol, 15, (3), 834-841, (2014)

6. A. ZAHRA, M. Z. HASHMI, R. N. MALIK, Z. AHMED: Enrichment and geoaccumulation of heavy metals and risk assessment of sediments of the Kurang Nallah-Feeding tributary of the Rawal Lake Reservoir, Pakistan, Science of the Total Environment (470 - 471), 925 - 933, (2014).

7. W. TANG, Y. ZHAO, C. WANG, B. SHAN, J. CUI: Heavy metal contamination of overlying waters and bed sediments of Haihe Basin in China, Ecotoxicology and Environmental Safety (98), 317 - 323, (2013).

8. J. FU, C. ZHAO, Y. LUO, C. LIU, G. Z. KYZA, Y. LUO, D. ZHAO, S. AN, H. ZHU: Heavy metals in surface sediments of the Jialu River, China: Their relations to environmental factors, Journal of Hazardous Materials (270), 102 109, (2014).

9. C. WANG, S. LIU, Q. ZHAO, L. DENG, S. DONG: Spatial variation and contamination assessment of heavy metals in sediments in the Manwan 
Reservoir, Lancang River, Ecotoxicology and Environmental Safety (82), 32 39, (2012).

10. Z. BANU, MD. S. A. CHOWDHURY, MD. D. HOSSAIN, K. NAKAGAMI: Contamination and Ecological Risk Assessment of Heavy Metal in the Sediment of Turag River, Bangladesh: An Index Analysis Approach, Journal of Water Resource and Protection, (5), 239 - 248, (2013).

11. M. CHABUKDHARA, A. K. NEMA: Assessment of heavy metal Contamination in Hindon River sediments: A chemometric and geochemical approach, Chemosphere (87), $945-953,(2012)$.

12. A. R. WIJAYA, A. K. OUCHI, K. TANAKA, M. D. COHEN, S. SIRIRATTANACHAI, R. SHINJO, S. OHDE: Evaluation of heavy metal contents and $\mathrm{Pb}$ isotopic compositions in the Chao Phraya River sediments: Implication for anthropogenic inputs from urbanized areas, Bangkok, Journal of Geochemical Exploration (126 - 127), 45 - 54, (2013).

13. L. KALENDER, S. C. UCAR: Assessment of metal contamination in sediments in the tributaries of the Euphrates River, using pollution indices and the determination of the pollution source, Turkey, Journal of Geochemical Exploration (134), 73 - 84, (2013).

14. E. A. M. SALAH, T. A. ZAIDAN, A. S. AL-RAWI: Assessment of heavy metals pollution in the sediments of Euphrates River, Iraq, Journal of Water Resource and Protection, (4), 1009 - 1023, (2012).

15. M. IORDACHE, A. MEGHEA, S. NEAMTU, L. R. POPESCU, I. IORDACHE: Evaluation of contamination with priority hazardous substances in Olt River water and sediments near the industrial platform of Ramnicu Valcea, REV. CHIM. (Bucharest) 65, (1), $87-93,(2014)$.

16. M. IORDACHE, L. R. POPESCU, I. IORDACHE, The application of pollution indexes in the assessment of heavy metal pollution in sediments, Progress of Cryogenics and Isotopes Separation, 17, (2), 129-140 (2014).

17. M. ILIE, F. MARINESCU, G. GHITA, GY. DEAK, G. S. TANASE, Assessment of heavy metal in water and sediments of the Danube River, J Environ Protect Ecol 15, (3), 825-833, (2014).

18. M. Mititelu, F. Nicolescu, C.-A. Ionita, T.-O. Nicolescu, Study of heavy metals and organic pollutants in some fishes of the Danube River, J Environ Protect Ecol 13, (2A), 869-874, (2012).

19. E. HRONCOVA, J. LADOMERSKY, V. DIRNER: The contamination of bottom sediments in water reservoirs in the vicinity of Banska Stiavnica (Slovakia) by potentially toxic elements, Carpathian Journal of Earth and Environmental Sciences, 9, (2), 199 - 207, (2014).

20. J. P.BRADY, G. A. AYOKO, W. N. MARTENS, A. GOONETILLEKE: Enrichment, distribution and sources of heavy metals in the sediments of Deception Bay, Queensland, Australia, Marine Pollution Bulletin (In press), (2014).

21. G. QINGJIE, D. JUN, X. YUNCHUAN, W. QINGFEI, Y. LIQIANG: Calculating pollution indices by heavy metals in ecological geochemistry assessment and a case study in Parks of Beijing, Journal of China University of Geosciences, 19, (3), $230-241,(2008)$.

22. S. NAZEER, H. M. ZAFFAR, R. N. MALIK: Heavy metals distribution, risk assessment and water quality characterization by water quality index of the River Soan, Pakistan, Ecological Indicators (43), 262 - 270, (2014).

23. MESDR, Order of Ministry (Ministry of Environment and Sustainable Development of Romania) no. 161/2006 for the approval of the Norms regarding the classification of surface water quality in order to establish the ecological status of the water body (2006). 